\title{
A MARSUPIAL ASSEMBLAGE (MAMMALIA, DIDELPHIMORPHIA) FROM THE QUATERNARY OF THE SERRA DA CAPIVARA, STATE OF PIAUÍ, BRAZIL
}

\author{
FILIPE ARMANDO MOTTA \\ Programa de Pós-Graduação em Geociências, Universidade Federal do Rio Grande do Sul, \\ Av. Bento Gonçalves, 9500, 91501-970, Porto Alegre, RS, Brasil. \\ filipe.motta00@gmail.com \\ PATRÍCIA HADLER, JORGE JOSÉ CHEREM \\ Departamento de Geologia, Universidade Federal de Santa Catarina, Campus \\ Universitário s/n, Trindade, 88900-000, Florianópolis, SC, Brasil. \\ patricia.hadler@ufsc.br;jjcherem@gmail.com \\ ANA MARIA RIBEIRO \\ Seção de Paleontologia, Museu de Ciências Naturais, SEMA, Av. Salvador França, 1427, \\ 90690-000, Porto Alegre, RS, Brasil. \\ ana-ribeiro@sema.rs.gov.br
}

\begin{abstract}
Didelphimorphia is one of the three extant marsupial orders in South America, and the only one currently found in Brazil. These marsupials have a wide variety of habits and occupy different habitats, making them good indicators of paleoenvironmental conditions. The Serra da Capivara National Park, located in the municipalities of São Raimundo Nonato, Coronel José Dias, João Costa and Brejo do Piauí, in the southeast of the State of Piauí, contains a large number of karstic caves and rock shelters in which hundreds of fossils of Pleistocene mammalian megafauna have been collected, together with small mammal fossils. This study reveals the diversity of didelphids in the Serra da Capivara through the analysis of fragmented maxillae and dentaries found in four paleontological sites: Toca do Serrote das Moendas, Toca do Gordo do Garrincho, Toca do Serrote do Artur and Toca do Barrigudo. The fossils were attributed to six taxa: Monodelphis domestica, Monodelphis americana, Didelphis albiventris, Cryptonanus agricolai, Gracilinanus agilis and Thylamys karimii. They constitute new records for the Quaternary of the Serra da Capivara, except for M. domestica and D. albiventris. Despite the megafauna indicating a Pleistocene age, radiocarbon dating of bioapatite from specimens of small mammals (marsupials and rodents) resulted in Holocene ages (5,550 \pm 40 years $\mathrm{BP}$ to $1,670 \pm 25$ years BP), showing temporal mixing in the studied sites. All the taxa described here are currently found in the Caatinga, suggesting stability in the taxonomic composition of the didelphid assemblage, at least since the Middle Holocene.
\end{abstract}

Keywords: Caatinga, Didelphidae, Holocene, karstic caves, rock shelters, taxonomy.

RESUMO - Didelphimorphia é uma das três ordens atuais de marsupiais na América do Sul, e a única registrada atualmente no Brasil. Esses marsupiais têm uma grande variedade de hábitos e ocupam diferentes habitats, tornando-os bons indicadores de condições paleoambientais. O Parque Nacional da Serra da Capivara, localizado nos municípios de São Raimundo Nonato, Coronel José Dias, João Costa e Brejo do Piauí, no sudeste do Estado do Piauí, contém um grande número de cavernas cársticas e abrigos rochosos, nos quais centenas de fósseis da megafauna de mamíferos do Pleistoceno foram coletadas, juntamente com fósseis de pequenos mamíferos. Este estudo revela a diversidade de didelfídeos na Serra da Capivara através da análise de maxilares e dentários fragmentados encontrados em quatro sítios paleontológicos: Toca do Serrote das Moendas, Toca do Gordo do Garrincho, Toca do Serrote do Artur e Toca do Barrigudo. Os fósseis foram atribuídos a seis táxons: Monodelphis domestica, Monodelphis americana, Didelphis albiventris, Cryptonanus agricolai, Gracilinanus agilis e Thylamys karimii. Eles constituem novos registros para o Quaternário da Serra da Capivara, exceto para M. domestica e D. albiventris. Apesar de a megafauna indicar uma idade plestocênica, datações radiocarbônicas de bioapatita de espécimes de pequenos mamíferos (marsupiais e roedores) resultaram em idades holocênicas (5.550 \pm 40 anos AP a $1.670 \pm 25$ anos AP), mostrando mistura temporal nos sítios estudados. Todos os táxons aqui descritos são atualmente encontrados na Caatinga, sugerindo estabilidade na composição taxonômica da associação de didelfídeos, pelo menos desde o Meso-holoceno.

Palavras-chave: Caatinga, Didelphidae, Holoceno, cavernas cársticas, abrigos rochosos, taxonomia. 


\section{INTRODUCTION}

The marsupials represent a clade of mammals distributed in the Americas and Oceania, currently comprising seven orders, of which Didelphimorphia, Paucituberculata and Microbiotheria have an exclusively American distribution (Flynn \& Wyss, 2004; Gardner, 2008; Voss \& Jansa, 2009). The species of marsupials currently found in Brazil belong to the family Didelphidae, the only Didelphimorphia family with living representatives (Rossi et al., 2012).

In South America, metatherians, a group that includes marsupials and all mammals more closely related to them than to placentals (Rowe, 1988), appear for the first time at the beginning of the Paleocene in the Lefipán Formation, in the Province of Chubut, Argentina (Goin et al., 2006). They diversified during the South American Cenozoic, becoming important components of the continent's fauna from the Paleocene to the Quaternary, comprising four orders and 19 families (Goin et al., 2016). In Brazil, fossils of marsupials are recorded in the lower Eocene of the Itaboraí Formation (Itaboraí Basin, Rio de Janeiro, RJ, Itaboraian South American Land Mammal Age/SALMA, 53-50 Ma) (Oliveira, 1999; Oliveira \& Goin, 2011; Woodburne et al., 2014; Carneiro, 2019), in the middle Eocene of the Guabirotuba Formation (Paraná Basin, Curitiba, PR, Barrancan SALMA, 42-39 Ma) (Sedor et al., 2017), in the upper Oligocene of the Tremembé Formation (Taubaté Basin, Taubaté, SP, Deseadan SALMA, 29-24 Ma) (Bergqvist \& Ribeiro, 1998; Dunn et al., 2013) and in Quaternary sediments (e.g. Paula Couto, 1950; Salles et al., 1999, 2006; Hadler et al., 2009a).

The fossil didelphids of the Quaternary of Brazil were first recorded in the work of the Danish naturalist Peter W. Lund in the mid 19th century, and later by Herluf Winge, who restudied the material collected by Lund in the limestone caves near the Municipality of Lagoa Santa, State of Minas Gerais (Winge, 1893; Paula Couto, 1950; Cartelle, 1999). In the last decades, Quaternary marsupials have also been described for Brazilian localities in the states of Goiás, Mato Grosso do Sul, São Paulo, Pernambuco, Rio Grande do Sul and Tocantins (Cartelle, 1999; Salles et al., 1999, 2006; Hadler et al., 2009a, b; Castro \& Langer, 2011; Oliveira et al., 2011a; Ferreira et al., 2012; Villa Nova et al., 2015).

In the Serra da Capivara, State of Piauí, didelphid remains have been collected in several caves and rock shelters, but they have not yet been studied in detail. There are references to the species of this group in faunal lists for only two sites: Toca da Janela da Barra do Antonião and Toca de Cima dos Pilão, with the following taxa being cited: cf. Didelphis albiventris (Lund, 1841), Monodelphis domestica (Müller, 1775), Marmosa cf. M. cinerea (Temmink, 1843) and Marmosa Gray, 1821 (Guérin et al., 1993, 1996; Guérin \& Faure, 2008). With this work, the knowledge about the marsupials of the Quaternary of the Serra da Capivara is expanded, registering new didelphid taxa from different sites to those already studied.

\section{STUDY AREA}

The Serra da Capivara National Park (SCNP) occupies an area of $1291.4 \mathrm{~km}^{2}$ and is located in the municipalities of São Raimundo Nonato, Coronel José Dias, João Costa and Brejo do Piauí, in the southeast of the State of Piauí, Brazil, at coordinates $08^{\circ} 26^{\prime} 50^{\prime \prime} \mathrm{S}$ and $08^{\circ} 54^{\prime} 23^{\prime \prime} \mathrm{S}$, and $42^{\circ} 19^{\prime} 47^{\prime \prime} \mathrm{W}$ and $42^{\circ} 45^{\prime} 51^{\prime \prime} \mathrm{W}$ (Figure 1). Some of the oldest archaeological sites in the Americas are located within the SCNP, from which lithic artifacts and human bones have been excavated. There are also several sites in the SCNP with rock art depicting the fauna and flora of the past (Guidon, 1994).

The SCNP is located on the southeastern boundary of the Parnaíba Basin. To the south, a huge escarpment (Cuesta) separates these formations from the São Francisco Basin. In the contact area between these two large basins are residual hills of metamorphic limestone of Precambrian age, called serrotes by the inhabitants of the region. These serrotes are located inside the $10 \mathrm{~km}$ buffer zone that surrounds the SCNP (Rodet, 1997; Santos \& Carvalho, 2009; Felice et al., 2014; Pellerin, 2014).

The paleontological sites in Serra da Capivara were first recorded in 1986, after the archaeological sites, with the discovery of mammalian fossils of Pleistocene megafauna in two localities near the SCNP. Later, several sites with mammal fossils were described in the same area (Guérin, 1991; Guérin et al., 1993; Guérin \& Faure, 2008). The paleontological sites are divided into two groups: (i) fluvial settings, likely to be the remnants of a larger river system; and (ii) limestone caves and rock shelters, slowly excavated by the action of water (Rodet, 1997; Mendes, 2016; Waldherr et al., 2017).

Among the caves and rock shelters, seven are especially notable for their quantity of fossils: Toca da Janela da Barra do Antonião, Toca de Cima dos Pilão, Sumidouro do Sansão, Toca do Serrote das Moendas, Toca do Gordo do Garrincho, Toca do Serrote do Artur and Toca do Barrigudo. The mammalian fossil fauna includes large specimens, such as the xenarthrans Megatheriidae, Mylodontidae, Pampatheriidae and Glyptodontidae, South American native ungulates Macraucheniidae and Toxodontidae, as well as the Holartic ungulates Tayassuidae, Camelidae, Equidae and Cervidae, which are already well studied (Faure et al., 1999; Guidon et al., 2000; Guérin \& Faure, 2004, 2008). An enormous amount of small mammal material has also been collected and its study has increased significantly in recent years. Mayer (2013) and Kerber et al. (2016) described fossils of caviomorph rodents from the Toca do Serrote das Moendas, Toca do Gordo do Garrincho, Toca do Serrote do Artur, Toca do Barrigudo and Sumidouro do Sansão, while Neves et al. (2017) recorded sigmodontine rodents for three sites: Toca do Serrote das Moendas, Toca do Gordo do Garrincho and Toca do Barrigudo. More recently, fossil bats were described from the Toca do Gordo do Garrincho, Toca do Serrote do Artur and Toca do Barrigudo sites (Hadler et al., 2018).

The fossils of didelphids studied here were collected at four sites: Toca do Serrote das Moendas, Toca do Gordo do Garrincho, Toca do Serrote do Artur and Toca do Barrigudo (Figure 1), described below: 


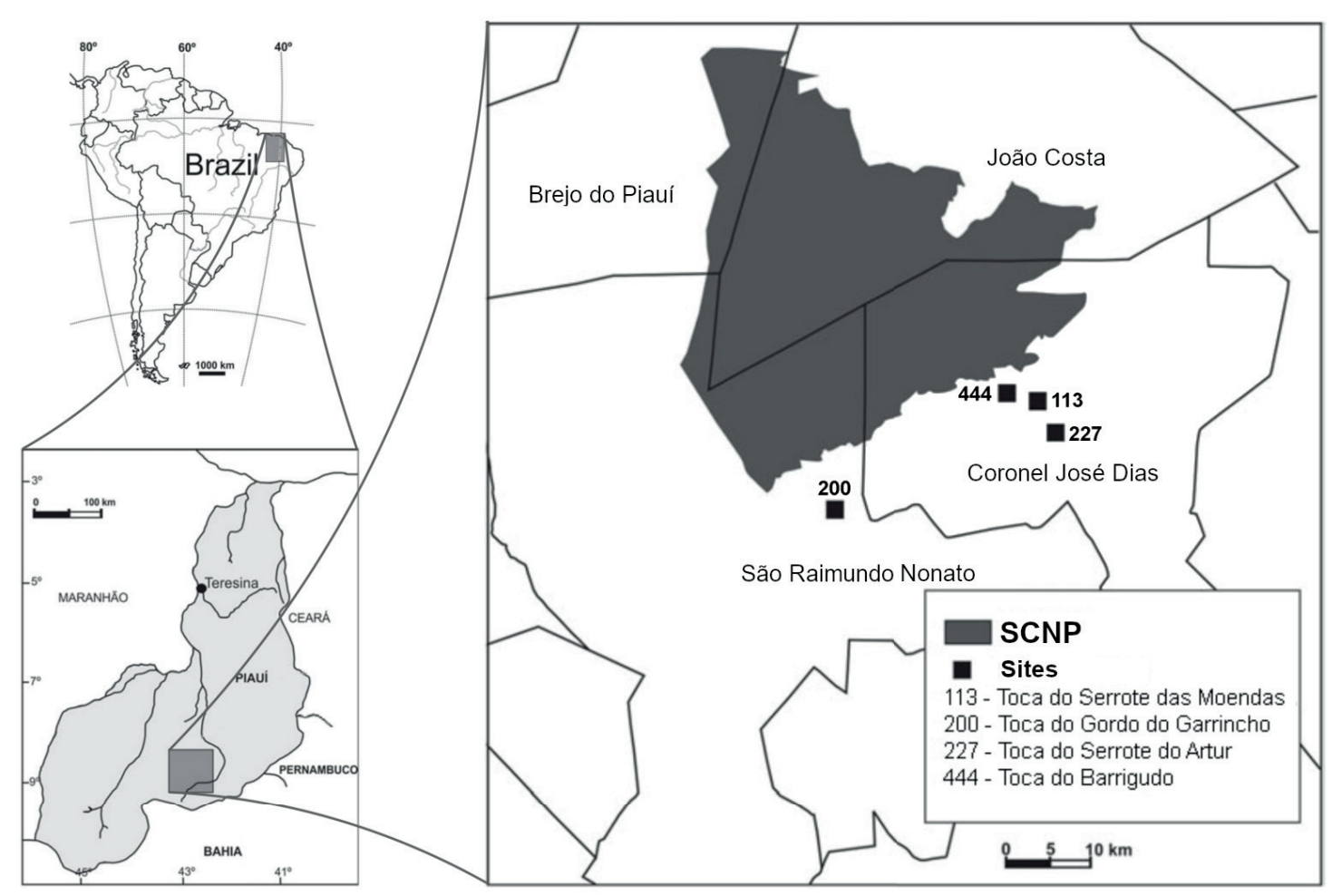

Figure 1. Map showing the location of the fossiliferous sites in the Serra da Capivara National Park (SCNP), State of Piauí, northeastern Brazil. Modified from Kerber et al. (2014).

\section{Toca do Serrote das Moendas - site number: 113}

The site is located in Serrote das Moendas, in the Municipality of Coronel José Dias, at coordinates $8^{\circ} 48^{\prime} 33^{\prime \prime} \mathrm{S}$ and $42^{\circ} 24^{\prime} 28^{\prime \prime} \mathrm{W}$. This site was studied in the early 2000 s, with the initial results published by Guidon et al. (2009). It is a sloping cave of approximately $35 \mathrm{~m}$ in length; the difference in height between the highest point, the entrance, and the lowest point is about $9 \mathrm{~m}$. In it were found three human skeletons and fossils of the Pleistocene mammalian megafauna. One of the human skeletons was found in association with Cervidae teeth, which were dated using the electron spin resonance (ESR) method, obtaining ages of $22,000 \pm 2,000$ and $23,000 \pm 2,000$ years BP. Most of the fossils of small mammals were collected in sectors 1 and 2, near the bottom of the cave. Two shells collected from the same level as the fossils of marsupials in sector 1 were dated by the radiocarbon method, indicating ages of $24,210 \pm 150$ years BP and 26,970 \pm 140 years BP (Guidon et al., 2009).

\section{Toca do Gordo do Garrincho - site number: 200}

This site is located in Serrote do Garrincho, in the Municipality of São Raimundo Nonato, at coordinates $8^{\circ} 55^{\prime} 29^{\prime \prime} \mathrm{S}$ and $42^{\circ} 36^{\prime} 29^{\prime \prime} \mathrm{W}$, and began to be excavated in 1991. It is a cave consisting of a corridor that extends from the entrance to a large chamber; both are filled with sandy sediment on a stalagmitic floor. Below this floor there is a layer of pebbles with a clayey matrix containing an abundance of mammalian fossils, among which the fossils of marsupials were collected. Charcoal fragments from the stalagmitic floor were dated as 10,020 \pm 290 years BP (Guérin, 1991; Guérin et al., 1996; Guidon et al., 2000).

\section{Toca do Serrote do Artur - site number: 227}

Located in the Serrote do Artur, in the Municipality of Coronel José Dias, at coordinates $8^{\circ} 49^{\prime} 49^{\prime \prime} \mathrm{S}$ and $42^{\circ} 24^{\prime} 21^{\prime \prime} \mathrm{W}$, this cave site was studied in 1995 and has produced a large quantity of megafauna fossils. It has an area of about $24 \mathrm{~m}^{2}$ and three stratigraphic layers. The first is a layer of dark silt, from which the fossils of small mammals originate. In this layer two radiocarbon datings were performed, one at the top $(6,890 \pm 60$ years BP $)$ and one at the base of the layer $(8,490$ \pm 120 years BP). Below, the second layer is a stalagmitic floor covering an erosive surface. Finally, the third layer is formed by reddish clayey sediments in which the mammalian megafauna fossils were collected (Faure et al., 1999; Guérin \& Faure, 2008).

\section{Toca do Barrigudo - site number: 444}

This site is located in Serrote da Bastiana, in the Municipality of Coronel José Dias $\left(8^{\circ} 48^{\prime} 17^{\prime \prime} \mathrm{S}\right.$ and $\left.42^{\circ} 24^{\prime} 52^{\prime \prime} \mathrm{W}\right)$. It is a sandstone rock shelter whose excavation began in 2002 . Several fossils of the Pleistocene megafauna were described 
from the site, such as Xenarthra, Litopterna, Cetartiodactyla and Perissodactyla, as well as human skeletons (Guérin \& Faure, 2004, 2008). Although the megafauna found in the site was considered to be of Pleistocene age (Guérin \& Faure, 2004), the bioapatite in some specimens of small mammals was recently dated by radiocarbon, resulting in Holocene ages: Kerodon rupestris (1,680 \pm 25 years BP), Thrichomys sp. $(1,670 \pm 25$ years BP; $3,940 \pm 25$ years BP; and 4,340 \pm 25 years BP) and Monodelphis domestica $(3,870 \pm 30$ years BP; 3,900 \pm 30 years BP; 4,370 \pm 35 years BP; and 5,550 \pm 40 years BP) (Ribeiro et al., 2016).

\section{MATERIAL AND METHODS}

The studied fossils, fragments of maxillae and dentaries, are deposited in the scientific collection of the Paleontology Sector of the Fundação Museu do Homem Americano (FUMDHAM). The preparation was done with the aid of tweezers, needles and brushes, and comparison was done, under a stereomicroscope, with recent specimens deposited in the mammal collections of the Mammalogy Sector of the Museu de Ciências Naturais of the Secretaria do Meio Ambiente e Infraestrutura (MCN/SEMA), the Universidade Federal de Pernambuco (UFPE) and the Ecology and Zoology Department of the Universidade Federal de Santa Catarina (UFSC), as well as with specialized literature (e.g. Goin, 2001; Voss et al., 2005; Carmignotto \& Monfort, 2006; Voss \& Jansa, 2009). The nomenclature of dental structures follows Oliveira \& Goin (2012) and the classification follows Voss \& Jansa (2009). The measurements were taken using a micrometer eyepiece coupled to the stereomicroscope, and the images were made using a Nikon AZ100M electronic stereoscopic microscope and software NIS-Elements AR v.4.3, and with a JEOL JSM-6060 scanning electron microscope. The minimum number of individuals (MNI) was calculated following Beisaw (2013). The specimens studied here are listed in Appendix 1, and extant specimens used for comparison are listed in Appendix 2.

Dental abbreviations: C, c, upper and lower canines, respectively; P1, P2, P3, p1, p2, p3, upper and lower first, second and third pre-molars, respectively; M1, M2, M3, M4, m1, m2, m3, m4, upper and lower first, second, third and fourth molars, respectively; LM1-M3, length from first to third upper molar; LM1-M4, Lm1-m4, Length of upper and lower molar series, respectively.

\section{SYSTEMATIC PALEONTOLOGY}

\author{
MAMMALIA Linnaeus, 1758 \\ METATHERIA Huxley, 1880 \\ MARSUPIALIFORMES Vullo et al., 2009 \\ NOTOMETATHERIA Kirsch et al., 1997 \\ MARSUPIALIA Illiger, 1811 (McKenna \& Bell, 1997) \\ Order DIDELPHIMORPHIA Gill, 1872 \\ Family DIDELPHIDAE Gray, 1821 \\ Subfamily DIDELPHINAE Gray, 1821
}

Material. One dentary from Toca do Serrote das Moendas, one dentary from Toca do Gordo do Garrincho, 18 dentaries from Toca do Serrote do Artur and 38 dentaries from Toca do Barrigudo (see Appendix 1).

Description. The material is very fragmented and toothless. The dentaries are small and delicate, with two mental foramina, one ventral to $\mathrm{p} 1$ and the other to $\mathrm{m} 1$, and very small alveoli.

Comments. The dentaries were separated from those attributed to Monodelphis domestica and M. americana by the smaller size of the alveoli. However, there are no characters that allow reliable generic identification, and they may be referable to the genera Marmosa, Cryptonanus, Gracilinanus or Thylamys.

Tribe MARMOSINI Hershkovitz, 1992

Monodelphis Burnett, 1830

Monodelphis domestica (Wagner, 1842)

(Figure 2)

Material. Nine dentaries from Toca do Serrote das Moendas, one maxillary and three dentaries from Toca do Gordo do Garrincho, 10 maxillae and 84 dentaries from Toca do Serrote do Artur, and 17 maxillae and 137 dentaries from Toca do Barrigudo (see Appendix 1).

Description. The infraorbital foramen and the anterior portion of the maxillopalatine fenestra are positioned at the level of P3. P2 and P3 have well-developed cinguli and P3 is slightly higher than P2. The upper molars are robust, with a conspicuous and incomplete anterolabial cingulum. In M1-M3, the stylar cusp C is generally absent and, when present, is poorly developed, and the stylar cusp D is very well developed. The ectoflexus is deep and slightly displaced anteriorly. The M4 has a vestigial metacone. The dentaries are tall and robust and have two mental foramina. The anterior cingulid is well developed, especially in $\mathrm{m} 2-\mathrm{m} 4$. The talonid is short, with the hypoconid labially displaced (except in $\mathrm{m} 3$ ), and the entoconid is reduced and distally displaced or absent. In $\mathrm{m} 4$ the talonid is labiolingually compressed and may present a well-marked cristid obliqua directed towards the post-protocristid.

Comments. The morphology of the ectoflexus, the absence/ reduction of the stylar cusp $\mathrm{C}$, the incomplete anterolabial cingulum in M3, the short talonid and the hypoconid not labially displaced on $\mathrm{m} 3$ are characteristics of Monodelphis (Goin \& Rey, 1997; Goin, 2001; Voss \& Jansa, 2009; Pavan $\&$ Voss, 2016). The position of the infraorbital foramen, the greater development of the anterior cingulid, the reduced but distinct entoconid, and the size of the Serra da Capivara specimens (Table 1) allow their attribution to the subgenus Monodelphis, according to Pavan \& Voss (2016). Although the diagnostic characteristics of the species of this subgenus are cranial or based on fur (Macrini, 2004), the specimens were attributed to $M$. domestica because it is the only species of similar size that occurs today in the Caatinga (Carmignotto 


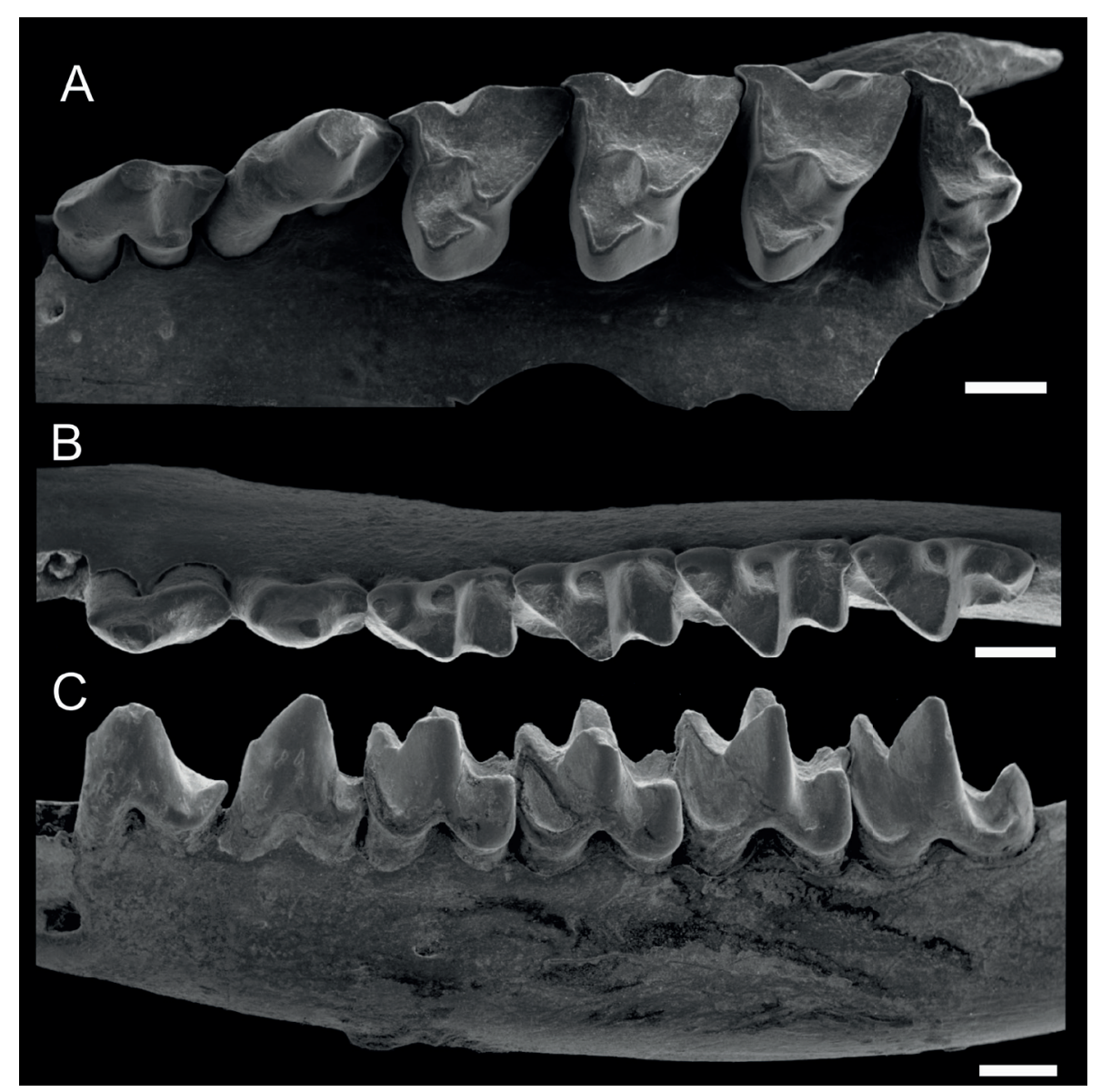

Figure 2. Monodelphis domestica. FUMDHAM 200-63207-2, left maxillary in occlusal view (A); FUMDHAM 227-47654-3A, left dentary in occlusal (B) and lateral $(\mathbf{C})$ views. Scale bars $=1 \mathrm{~mm}$.

\& Astúa, 2017), and because of their similarity to the recent specimens used for comparison (Appendix 2). The values obtained for the length of the molar series of the Serra da Capivara specimens (Table 1) are within the range recorded by Gomes (1991) for M. domestica (LM1-M4 = 7.04 to 8.94 $\mathrm{mm}$; $\mathrm{Lm} 1-\mathrm{m} 4=8.22$ to $10.02 \mathrm{~mm}$ ).

\section{Monodelphis americana (Müller, 1776)}

(Figure 3)

Material. FUMDHAM 227-47646-3A, right dentary with m1, m3-m4 from Toca do Serrote do Artur.

Description. The dentary is small, tall and robust. The anterior margin of the mandibular ramus is slightly inclined posteriorly. It presents two mental foramina, the anterior one ventral to the border between $\mathrm{p} 1$ and $\mathrm{p} 2$, and the posterior one ventral to $\mathrm{m} 1$. The anterior cingulid is well developed, especially in $\mathrm{m} 3-\mathrm{m} 4$. The talonid is short, with a developed and distinct entoconid. In $\mathrm{m} 4$ the talonid is labiolingually compressed, with a conspicuous cristid obliqua parallel to the anteroposterior axis of the tooth. $\mathrm{Lm} 1-\mathrm{m} 4=7.1 \mathrm{~mm}$.

Comments. The specimen is similar to Monodelphis domestica, but smaller (Table 1). Currently, Monodelphis americana is the only small species of the genus recorded in the Caatinga (Carmignotto \& Astúa, 2017). The length of the lower molar series for this species ranges from 6.00 to 7.04 $\mathrm{mm}(\mathrm{n}=19)$, according to Gomes (1991). Considering that the length of the Serra da Capivara material is very close to the upper limit for the species, we chose to attribute it to $M$. americana.

Tribe DIDELPHINI Gray, 1821

\section{Didelphis Linnaeus, 1758}

Didelphis albiventris Lund, 1840

(Figure 4)

Material. One dentary from Toca do Serrote das Moendas, three dentaries and one isolated tooth from Toca do Serrote do Artur and seven dentaries from Toca do Barrigudo (Appendix 1).

Description. The material is very fragmented and the teeth are worn. Despite this, it is observed that the dentaries are large and robust, the molars have a protoconid and paraconid of similar size and the metaconid is the smaller cusp of the trigonid in the $\mathrm{m} 3$ and $\mathrm{m} 4$. The anterior cingulid is moderately developed. The talonid is complete, with a distinct entoconid and hypoconulid, including in the $\mathrm{m} 4$. 
Comments. The general morphology and size allow the referral of the material to the genus Didelphis. The length of the alveolus of $\mathrm{p} 2$ coincides with that of recent specimens of $D$. albiventris, being smaller than $D$. aurita (Wied-Neuwied, 1826) and D. marsupialis Linnaeus, 1758 (sensu Astúa, 2015). Didelphis albiventris is the only species of the genus with a current distribution in the Caatinga (Carmignotto \& Astúa, 2017).

Table 1. Measurements (in $\mathrm{mm}$ ) of the Serra da Capivara specimens of Monodelphis domestica.

\begin{tabular}{|c|c|c|c|}
\hline \multicolumn{4}{|c|}{ Monodelphis domestica } \\
\hline & LM1-M3 & LM1-M4 & Lm1-m4 \\
\hline FUMDHAM 113-122546-2 & --- & --- & 9.1 \\
\hline FUMDHAM 113-138001 & --- & --- & 9.9 \\
\hline FUMDHAM 113-143298-3 & --- & --- & 9.3 \\
\hline FUMDHAM 113-144938 & --- & --- & 9.8 \\
\hline FUMDHAM 200-60900-3A & --- & --- & 9.2 \\
\hline FUMDHAM 200-63207-2 & 6.7 & 8.3 & --- \\
\hline FUMDHAM 227-47437-5A(1) & --- & --- & 9.6 \\
\hline FUMDHAM 227-47437-5A(2) & 7.3 & 8.5 & --- \\
\hline FUMDHAM 227-47440-3A & 7.6 & 8.9 & --- \\
\hline FUMDHAM 227-47445-2 & --- & --- & 9.3 \\
\hline FUMDHAM 227-47446-1C & 7.1 & 8.3 & --- \\
\hline FUMDHAM 227-47654-3A & --- & --- & 9.4 \\
\hline FUMDHAM 227-47664-3 & 7.0 & 8.1 & --- \\
\hline FUMDHAM 227-47950-4A & 7.0 & 8.3 & --- \\
\hline FUMDHAM 227-47952-4A & --- & --- & 9.4 \\
\hline FUMDHAM 444-76185-2B & --- & --- & 9.6 \\
\hline FUMDHAM 444-78424-6D(1) & 7.0 & 8.1 & --- \\
\hline FUMDHAM 444-78424-6D(2) & 7.6 & 9.1 & --- \\
\hline FUMDHAM 444-78429-7C(1) & --- & --- & 9.3 \\
\hline FUMDHAM 444-78429-7C(2) & 6.7 & --- & --- \\
\hline FUMDHAM 444-78429-7C(3) & 6.7 & --- & --- \\
\hline FUMDHAM 444-78438-4A & 6.9 & --- & --- \\
\hline FUMDHAM 444-78903-4A(1) & --- & --- & 9.3 \\
\hline FUMDHAM 444-78903-4A(2) & --- & --- & 9.1 \\
\hline FUMDHAM 444-78911-3A & 6.9 & 8.0 & --- \\
\hline FUMDHAM 444-78913A & --- & --- & 9.3 \\
\hline FUMDHAM 444-79156-5D(1) & 6.6 & 7.6 & --- \\
\hline FUMDHAM 444-79156-5D(2) & 7.0 & 8.1 & --- \\
\hline FUMDHAM 444-79156-5D(3) & --- & --- & 9.1 \\
\hline FUMDHAM 444-79156-5D(4) & --- & --- & 9.8 \\
\hline FUMDHAM 444-79156-5D(5) & --- & --- & 9.6 \\
\hline
\end{tabular}

Tribe THYLAMYINI Hershkovitz, 1992

Cryptonanus Voss, Lunde \& Jansa, 2005

Cryptonanus agricolai (Moojen, 1943)

(Figure 5)
Material. Four dentaries from Toca do Serrote das Moendas, six dentaries from Toca do Serrote do Artur and one dentary from Toca do Barrigudo (Appendix 1).

Description. The dentaries are delicate, but tall. The anterior cingulid is poorly developed, but more than in the specimens of Gracilinanus. There is a well-marked labial cingulid in $\mathrm{m} 1-$ $\mathrm{m} 3$, which does not reach the anterior cingulid except in two specimens (FUMDHAM 444-76185-2A and FUMDHAM 22748405-4B). The entoconid is conspicuous, but its base is smaller than in Gracilinanus. The entoconid and the hypoconulid are twinned, the hypoconulid being on the posterolingual margin of the talonid. The hypoconid is labially projected to the level of the labial apex of the protoconid in $\mathrm{m} 3$. The cristid obliqua in $\mathrm{m} 3$ presents a sigmoid aspect in a posterolabial-anterolingual sense. The talonid in $\mathrm{m} 4$ is labiolingually compressed when compared to that of Gracilinanus.

Comments. In the SCNP material the hypoconid is not as labially projected as in the Gracilinanus material, which concurs with the data of Voss \& Jansa (2009). In addition, the reduced size (Table 2) and the presence of a marked labial cingulid makes it possible to identify the material as Cryptonanus agricolai, the only species of the genus currently found in the Caatinga (Voss et al., 2005; Carmignotto \& Astúa, 2017).

Table 2. Measurements (in $\mathrm{mm}$ ) of the Serra da Capivara specimens of Cryptonanus agricolai and Gracilinanus agilis.

\begin{tabular}{lc}
\hline \multicolumn{2}{c}{ Cryptonanus agricolai } \\
\hline & Lm1-m4 \\
\hline FUMDHAM 113-137857-3 & 5.6 \\
FUMDHAM 227-48405-4B & 5.4 \\
FUMDHAM 227-48455-2A & 5.5 \\
Gracilinanus agilis & \\
FUMDHAM 444-78429-7A(1) & 6.6 \\
FUMDHAM 444-78429-7A(2) & 6.4 \\
FUMDHAM 444-78429-7A(3) & 6.4 \\
FUMDHAM 444-78429-7A(4) & 6.2 \\
FUMDHAM 444-78429-7A(5) & 6.6 \\
FUMDHAM 444-78429-7A(6) & 6.6 \\
FUMDHAM 444-79156-5A(1) & 6.4 \\
FUMDHAM 444-79156-5A(2) & 6.6 \\
FUMDHAM 227-48405-4A & 6.6 \\
FUMDHAM 113-144366-2 & 6.4 \\
\hline
\end{tabular}

Gracilinanus Gardner \& Creighton, 1989

Gracilinanus agilis (Burmeister, 1854)

(Figure 6)

Material. One dentary from Toca do Serrote das Moendas, one dentary from Toca do Gordo do Garrincho, seven dentaries from Toca do Serrote do Artur and 20 dentaries from Toca do Barrigudo (Appendix 1). 


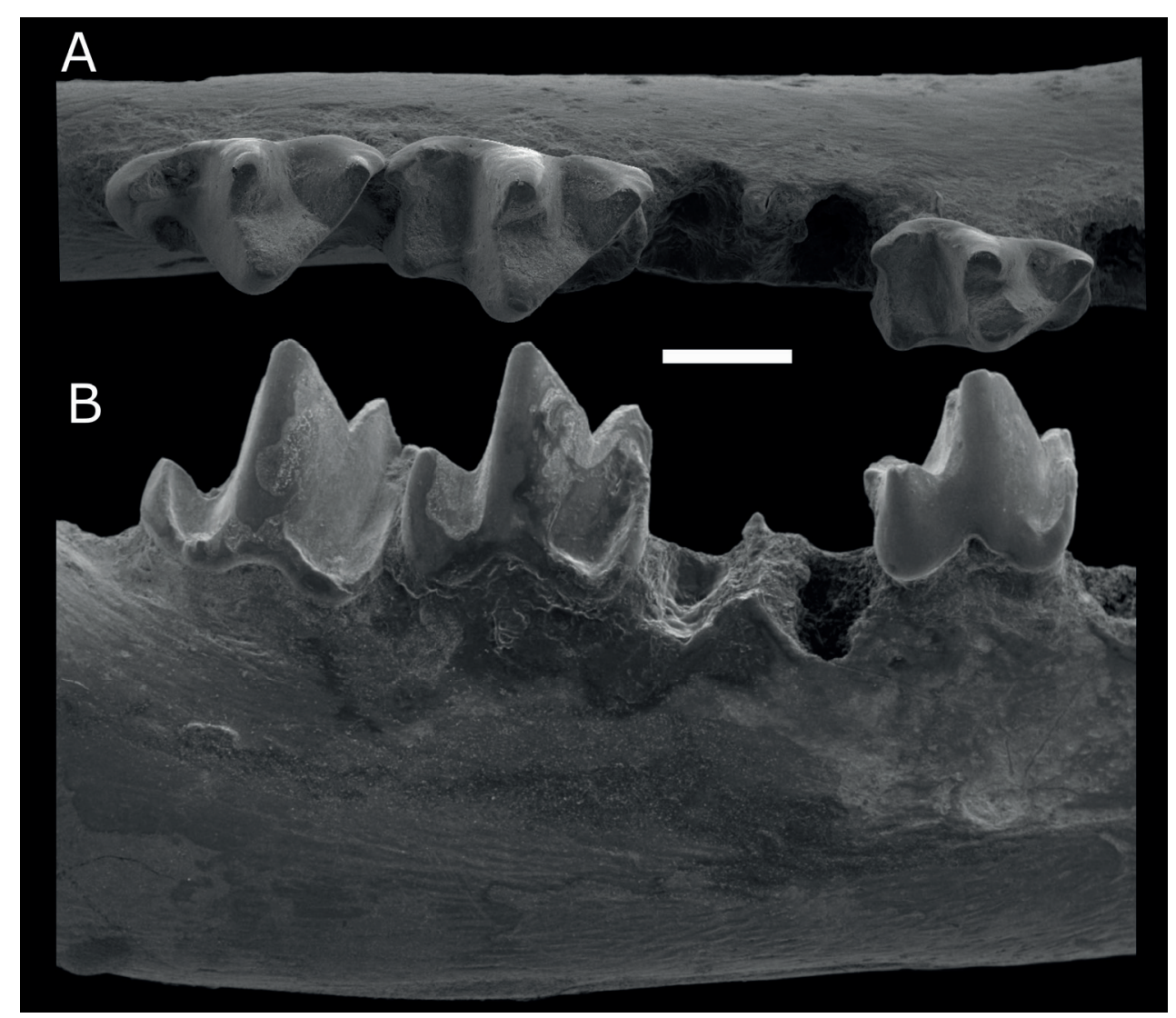

Figure 3. Monodelphis americana. FUMDHAM 227-47646-3A, right dentary in occlusal (A) and lateral (B) views. Scale bar $=1 \mathrm{~mm}$.

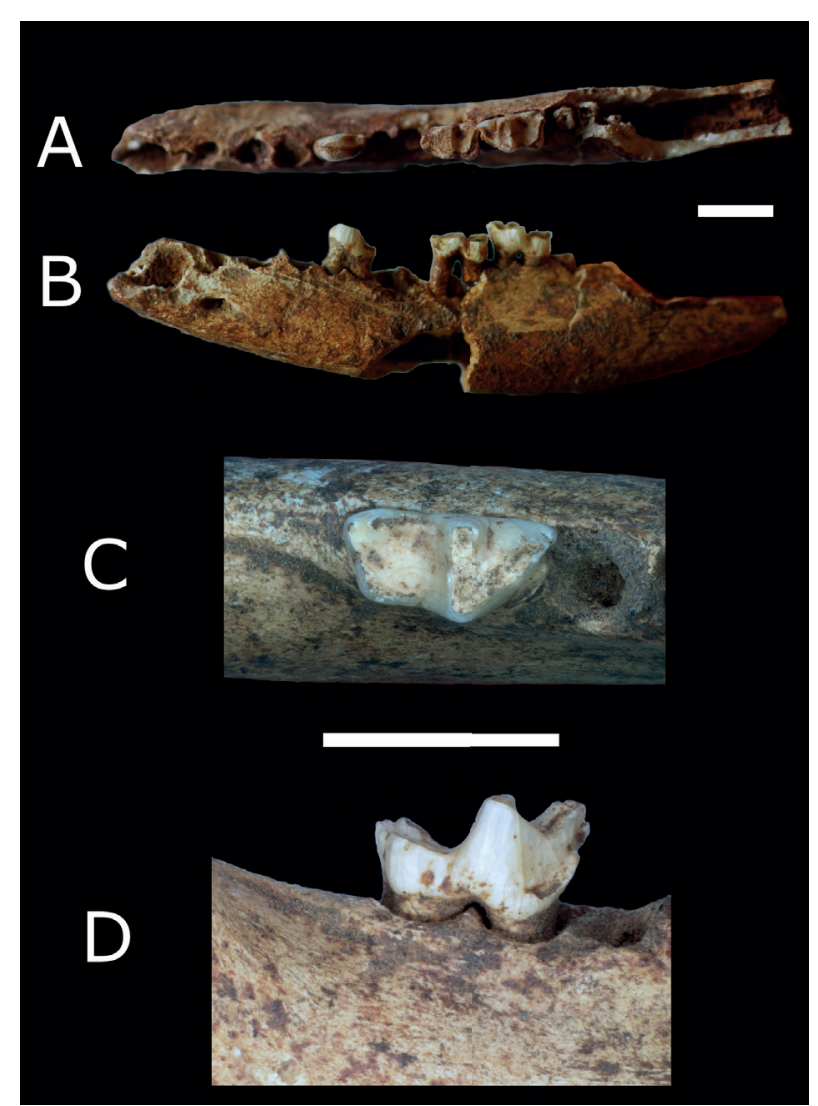

Figure 4. Didelphis albiventris. FUMDHAM 444-77783, left dentary in occlusal (A) and lateral (B) views; FUMDHAM 444-77765, right dentary in occlusal (C) and lateral (D) views. Scale bars $=5 \mathrm{~mm}$.
Description. The dentaries are tall, but delicate. The anterior cingulid is poorly marked, especially in $\mathrm{m} 1$ and $\mathrm{m} 2$, and is less developed than in Cryptonanus. The labial cingulid is absent. The entoconid is well developed, with a broad base. The hypoconid is labially projected, exceeding the protoconid line, especially in $\mathrm{m} 3$. In addition, the cristid obliqua presents a rectilinear aspect in a posterolabial-anterolingual sense.

Comments. The material resembles that of Gracilinanus agilis used for comparison (Appendix 2) and has a more labially projected hypocononid in $\mathrm{m} 3$ than in the Cryptonanus material. Unlike Cryptonanus and G. microtarsus, in $G$. agilis the labial cingulid is absent. In addition, Gracilinanus has a smaller anterior cingulid than in Cryptonanus and a larger lower molar series (Table 2). Gracilinanus agilis is the only species of the genus widely distributed in the Caatinga (Carmignotto \& Astúa, 2017).

\section{Thylamys Gray, 1843}

\section{Thylamys karimii (Petter, 1968) \\ (Figure 7)}

Material. One maxillary and four dentaries from Toca do Serrote do Artur and one maxillary and five dentaries from Toca do Barrigudo (Appendix 1).

Description. The posterolateral palatal foramen is very large, with the anterior border reaching the metacone of the M3. The canine has two small accessory cusps, one anterior and one posterior. The P3 is higher than the P2. The upper molars 


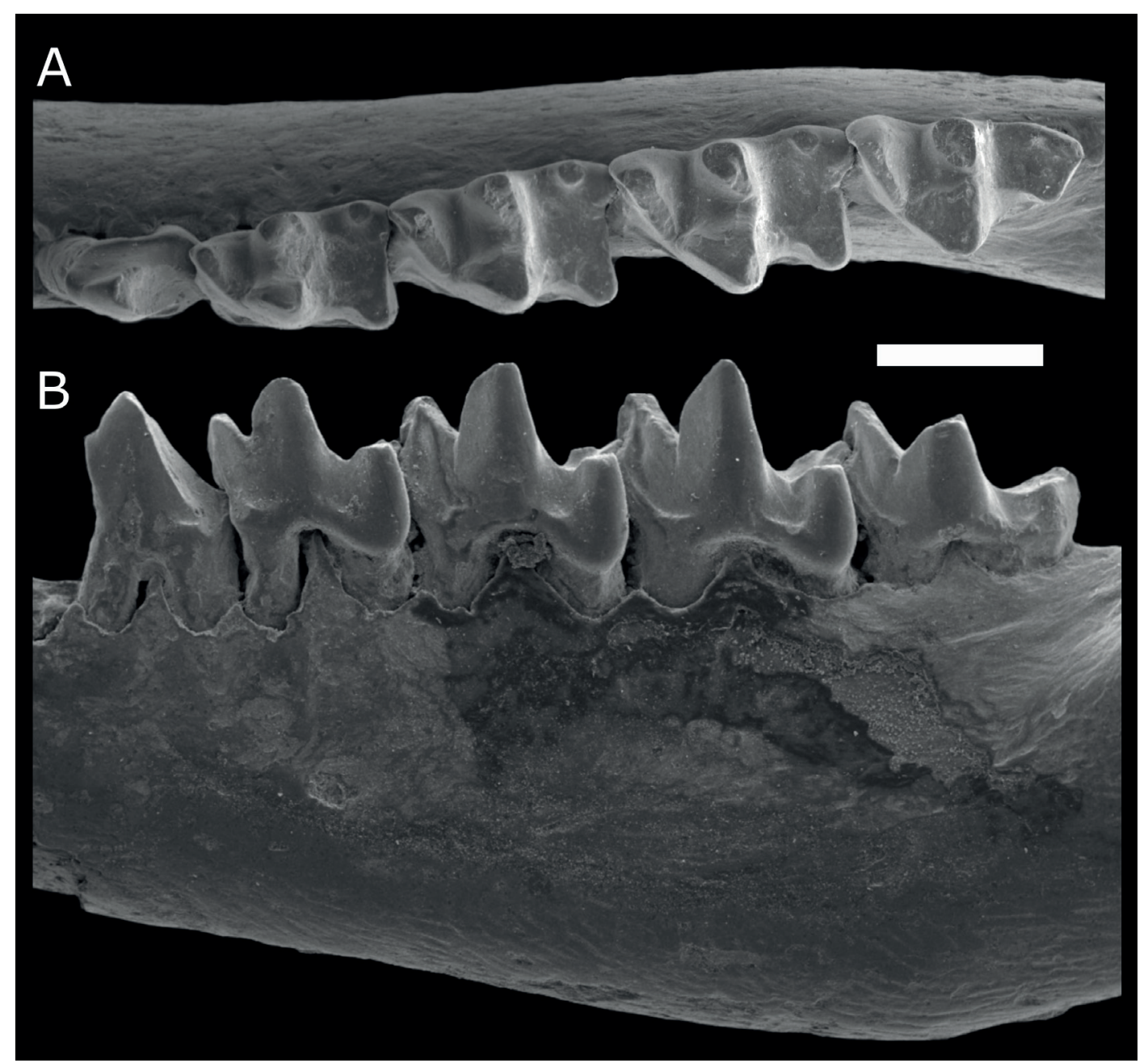

Figure 5. Cryptonanus agricolai. FUMDHAM 227-48455-2A, left dentary in occlusal (A) and lateral (B) views. Scale bar $=1 \mathrm{~mm}$.
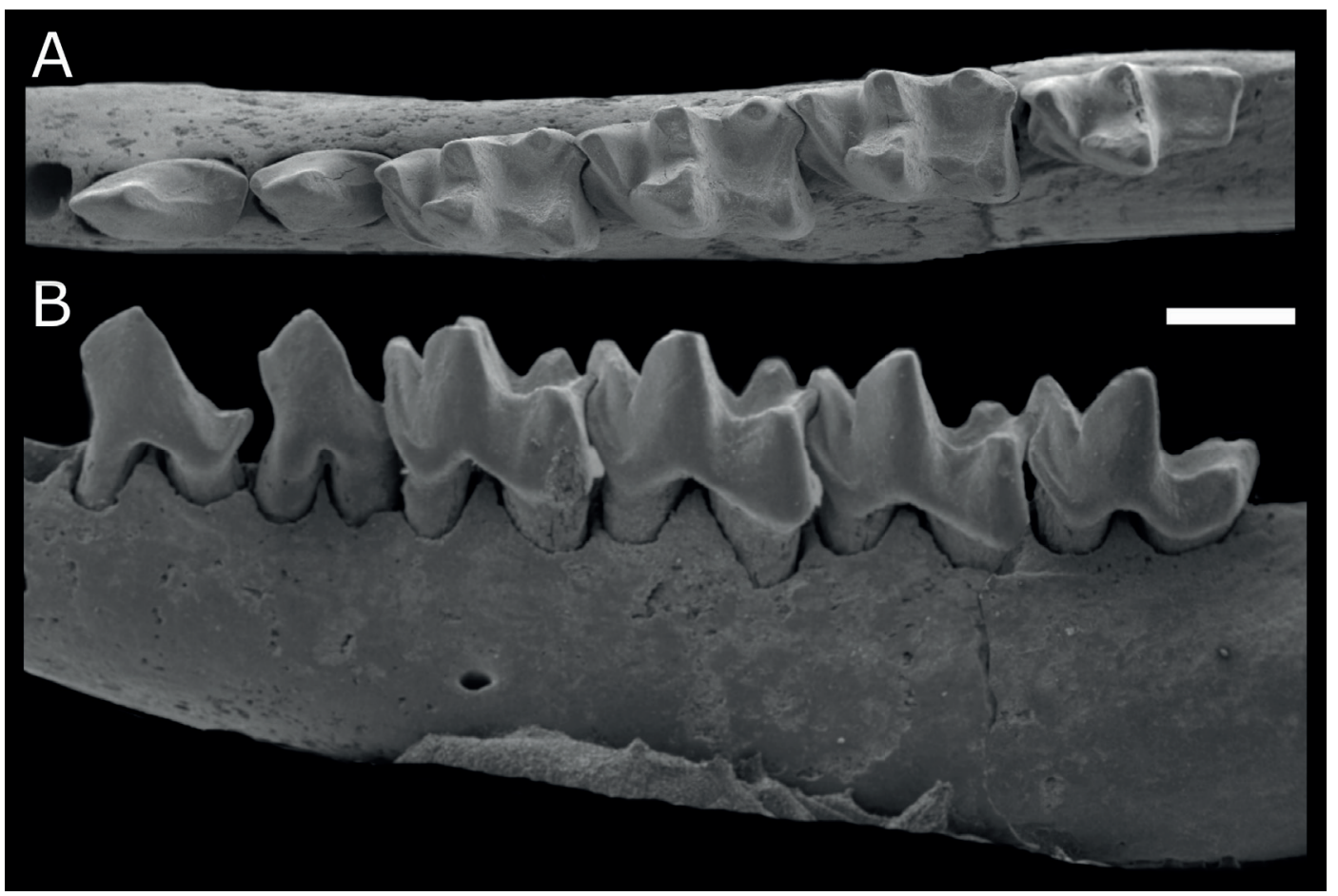

Figure 6. Gracilinanus agilis. FUMDHAM 113-144366-2, left dentary in occlusal (A) and lateral (B) views. Scale bar = $1 \mathrm{~mm}$. 


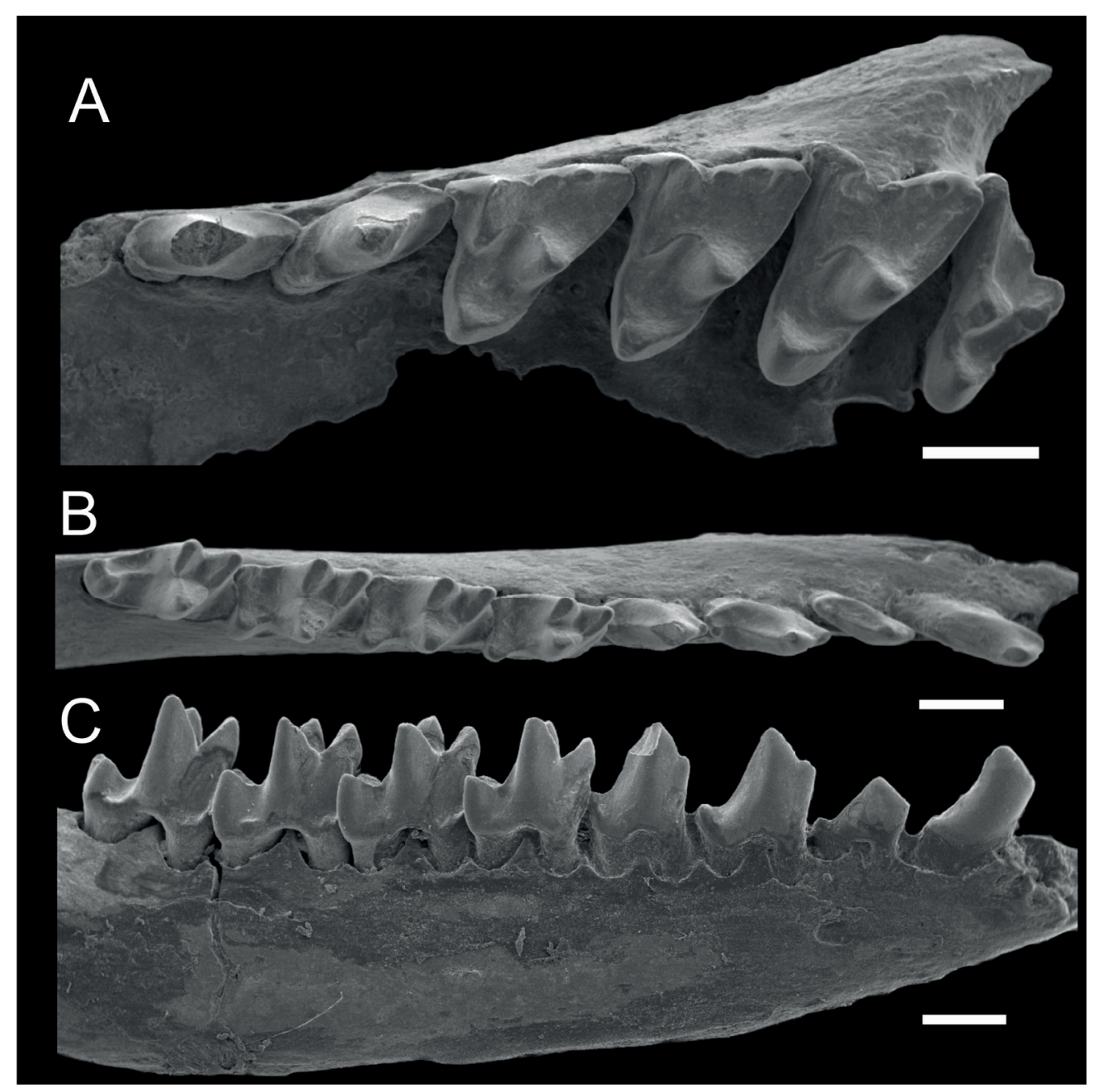

Figure 7. Thylamys karimii. FUMDHAM 44478424-6B, left maxillary in occlusal view (A); FUMDHAM 227-45004-4A, right dentary in occlusal (A) and lateral (B) views. Scale bars $=1 \mathrm{~mm}$.

are anteroposteriorly compressed and have a well-developed stylar cusp C. The ectoflexus is quite pronounced in M3. The anterolabial cingulid is incomplete. The lower molars present an anteroposteriorly compressed trigonid, and the metaconid and paraconid are closer to each other. The anterior cingulid is well developed, especially from $\mathrm{m} 2$ to $\mathrm{m} 4$. The talonid is short and presents a labial cingulid. The hypoconid is labially projected in $\mathrm{m} 1-\mathrm{m} 3$, and the entoconid and the hypoconulid are greatly reduced and are virtually fused. In the $\mathrm{m} 4$ the talonid is labiolingually compressed, especially in the posterior portion, and the cristid obliqua is conspicuous and positioned parallel to the anteroposterior axis of the tooth. Comments. The anteroposterior compression of the upper molars and the trigonids of the lower molars, the $\mathrm{P} 3$ being higher than P2, the well-developed stylar cusp C, the labially projected hypoconid and the large posterolateral palatal foramen allow the assignment of the material to Thylamys, according to Goin (2001), Carmignotto \& Monfort (2006), Hadler et al. (2009b) and Voss \& Jansa (2009). In comparison with the studied Gracilinanus and Cryptonanus specimens, in addition to the previously mentioned characteristics, Thylamys presents a more-developed anterior cingulid, shorter talonid and less-developed entoconid. The large posterolateral palatal foramen with the border extending up to the $\mathrm{M} 3$ metacone is consistent with the species Thylamys karimii, which currently occurs in the Caatinga (Carmignotto \& Monfort, 2006).

\section{DISCUSSION AND CONCLUSIONS}

\section{Taxonomy}

The Quaternary marsupial fauna studied here is an important association recorded for the Serra da Capivara National Park, State of Piauí, consisting of six species in five genera (Table 3). The species Thylamys karimii and Cryptonanus agricolai are recorded for the first time for the Quaternary of Brazil and Gracilinanus agilis for the Quaternary of the State of Piauí.

Previous works on the Serra da Capivara Quaternary fossils listed Monodelphis domestica, cf. Didelphis albiventris and Marmosa sp. for the Toca da Janela da Barra do Antonião site, and Monodelphis domestica and Marmosa sp. for the Toca de Cima dos Pilão site (Guérin et al., 1993, 1996). Of these, only Marmosa was not found in the four sites studied 
Table 3. Number of specimens of each taxon identified in the study separated by site. In parentheses, minimum number of individuals.

\begin{tabular}{lcccc}
\hline \multirow{2}{*}{ Taxon } & \multicolumn{4}{c}{ Sites } \\
\cline { 2 - 5 } & 113 & 200 & 227 & 444 \\
\hline Didelphinae & $1(1)$ & $1(1)$ & $18(12)$ & $38(20)$ \\
Monodelphis domestica & $9(5)$ & $4(2)$ & $94(42)$ & $154(70)$ \\
Monodelphis americana & --- & --- & $1(1)$ & --- \\
Didelphis albiventris & $1(1)$ & --- & $4(2)$ & $7(4)$ \\
Cryptonanus agricolai & $4(3)$ & --- & $7(5)$ & $1(1)$ \\
Gracilinanus agilis & $1(1)$ & $1(1)$ & $7(4)$ & $20(12)$ \\
Thylamys karimii & --- & --- & $5(2)$ & $5(3)$ \\
\hline
\end{tabular}

here. Due to the significant changes that have occurred in Didelphidae systematics in recent decades (e.g. Voss et al., 2001, 2005, 2014; Palma et al., 2002; Pavan \& Voss, 2016), a review of the material from these sites is necessary to confirm the taxonomic status of the specimens attributed to Marmosa.

For the Quaternary of the Northeast of Brazil, there are records of marsupials from only four other localities. In the caves around the Ubajara National Park, State of Ceará, Monodelphis sp. and Didelphis sp. were recorded (Oliveira, 2010; Oliveira et al., 2011b). For the Alcobaça site, a sandstone rock shelter located in Catimbau National Park, Buíque, State of Pernambuco, Monodelphis sp. was recorded (Ferreira et al., 2012). For the State of Rio Grande do Norte, only the genus Didelphis was reported from a cave in the locality of Lajedo da Escada, in the municipality of Baraúna (Araújo-Júnior \& Porpino, 2011). As for the State of Bahia, Cartelle (1999) listed four taxa, also collected in caves: Micoureus cinereus (= Marmosa demerarae), Monodelphis domestica, Didelphis albiventris and Gracilinanus agilis.

\section{Taphonomy, dating and paleoenvironment}

Several variables may interfere with the accumulation of skeletal remains in caves: (i) the morphology of the cave, (ii) its internal fluvial dynamics, (iii) the fauna that lives inside and in its surroundings, and (iv) water or mud flows that carry sediment along with the surrounding carcasses or bones into the cave system. All these aspects, together with protection and the dry environment, contribute to fossilization (Andrews, 1990). However, the same dynamics that favor these accumulations also strongly interfere with the stratigraphy of cave deposits. Reworking and temporal mixing are very common, which hinders a stratigraphic and geochronological correlation (Auler et al., 2006). For this reason, although the dating of materials found with the small mammal fossils indicates an end-Pleistocene age for the Toca do Serrote das Moendas site and a earliest Holocene age for the Toca do Serrote do Artur and Toca do Gordo do Garrincho sites, it is not possible to accurately determine the age of the didelphids studied here. In the Toca do Barrigudo site, the radiocarbon datings made on bioapatite from specimens of marsupials collected in the same stratum showed some degree of temporal mixing (between 5,550 \pm 40 years BP and $1,670 \pm 25$ years BP) (Ribeiro et al., 2016), suggesting that the didelphid fauna has remained the same, at least since the Middle Holocene. However, since only one site was dated using marsupial material, it was decided to refer the studied material to the Quaternary and not to a more specific epoch.

In surveys of current living fauna in the surroundings of the SCNP, Didelphis albiventris, Monodelphis domestica, Gracilinanus agilis and Marmosa sp. were recorded (Guidon, 1994; Herrera et al., 2005; Silva et al., 2011). Besides, all the didelphids identified here currently live in the Caatinga, according to Carmignotto \& Astúa (2017).

Although the material studied suggests that from the Pleistocene/Holocene transition the assemblage of didelphids remained stable in terms of taxonomic composition in the SCNP, the same did not occur with other groups of small mammals. Among sigmodontine rodents, Neves et al. (2017) described fossils of Bibimys sp., a locally extinct genus. This genus currently occurs in Argentina, Paraguay and in the South and Southeast regions of Brazil in open environments close to forests (Patton et al., 2015), which are more humid and colder environments than those currently found in the Serra da Capivara. Among caviomorph rodents, Kerber et al. (2016) described an extinct genus exclusive to the Serra da Capivara, Niedemys, and at least three more locally extinct taxa, associated with a more humid climate: Hydrochoeridae, cf. Myocastor, and Phyllomys. Regarding the bats, Hadler et al. (2018) also reported a local extinction of Eptesicus fuscus. This species had a considerably larger geographical distribution during the Quaternary, with fossil records in Rio Grande do Sul and Bahia (Czaplewski \& Cartelle, 1998; Hadler et al., 2010). Currently it only occurs in northwestern South America (Gardner, 2008).

The Northeast region of Brazil suffered an alternation of dry and humid climates during the Late Pleistocene. After this period of instability at the Pleistocene/Holocene transition, the climate of this region became hotter and drier, approaching what it is today in terms of environment and floral composition (Behling et al., 2000; Prado et al., 2013; Novello et al., 2017). It is possible that these climatic and environmental changes indicated by palynological and speleological data may be responsible for the local extinctions of small mammal taxa. Understanding these distinct extinction patterns for different groups of small mammals requires further study of both fossil and living fauna and is an important theme for future works.

\section{ACKNOWLEDGEMENTS}

The authors would like to thank to N. Guidon for loaning the material, to curators A. Valli (FUMDHAM), M.M.A. Jardim and T.C. Trigo (MCN/SEMA), D. Astúa (UFPE), P.C. Simões-Lopes and M.E. Graipel (UFSC) for assistance during the visits, and to the Centro de Microscopia e Microanálise at UFRGS for the images. To S. Pavan, for assistance in identifying the specimens of Monodelphis. To E.V. Oliveira and an anonymous reviewer for suggestions on the manuscript. To CNPq (312085/2013-3 and 483156/2012) for financial support. This study was financed in part by the Coordenação de Aperfeiçoamento de Pessoal de Nível Superior - Brasil (CAPES) - Finance Code 001. 


\section{REFERENCES}

Andrews, P. 1990. Owls, caves and fossils: predation, preservation, and accumulation of small mammal bones in caves, with an analysis of the Pleistocene cave faunas from Westbury-SubMendip, Somerset, UK. Chicago, University of Chicago Press, $231 \mathrm{p}$.

Araújo-Júnior, H.I. \& Porpino, K.O. 2011. Assembleias fossilíferas de mamíferos do Quaternário do Estado do Rio Grande do Norte, Nordeste do Brasil: diversidade e aspectos tafonômicos e paleoecológicos. Pesquisas em Geociências, 38:67-83. doi:10.22456/1807-9806.23836

Astúa, D. 2015. Morphometrics of the largest New World marsupials, opossums of the genus Didelphis (Didelphimorphia, Didelphidae). Oecologia Australis, 19:117-142.

Auler, A.S.; Piló, L.B.; Smart, P.L.; Wang, X.; Hoffmann, D.; Richards, D.A.; Edwards, R.L.; Neves, W.A. \& Cheng, H. 2006. U-series dating and taphonomy of Quaternary vertebrates from Brazilian caves. Palaeogeography, Palaeoclimatology, Palaeoecology, 240:508-522. doi:10.1016/j.palaeo.2006.03.002

Behling, H.; Arz, H.; Pätzold, J. \& Wefer, G. 2000. Late Quaternary vegetational and climate dynamics in northeastern Brazil, inferences from marine core GeoB 3104-1. Quaternary Science Reviews, 19:981-994. doi:10.1016/S0277-3791(99)00046-3

Beisaw, A.M. 2013. Identifying and interpreting animal bones: a manual. College Station, Texas A \& M University Press, 192 p.

Bergqvist, L.P. \& Ribeiro, A.M. 1998. A paleomastofauna das bacias eoterciárias brasileiras e sua importância na datação das bacias de Itaboraí e Taubaté. Buenos Aires, La Asociación Paleontológica Argentina, p. 19-34 (Publicaciones Especiales 1).

Carmignotto, A.P. \& Astúa, D. 2017. Mammals of the Caatinga: diversity, ecology, biogeography, and conservation. In: J.M.C. Silva; I.R. Leal \& M. Tabarelli (eds.) Caatinga, Springer, p. 211-254. doi:10.1007/978-3-319-68339-3_8

Carmignotto, A.P. \& Monfort, T. 2006. Taxonomy and distribution of the Brazilian species of Thylamys (Didelphimorphia: Didelphidae). Mammalia, 70:126-144. doi:10.1515/ MAMM.2006.013

Carneiro, L.M. 2019. A new protodidelphid (Mammalia, Marsupialia, Didelphimorphia) from the Itaboraí Basin and its implications for the evolution of the Protodidelphidae. Anais da Academia Brasileira de Ciências, 91:e20180440. doi:10.1590/00013765201820180440

Cartelle, C. 1999. Pleistocene mammals of the Cerrado and Caatinga of Brazil. In: J.F. Eisenberg \& K.H. Redford (eds.) Mammals of the Neotropics, University of Chicago Press, p. 27-46.

Castro, M.C. \& Langer, M.C. 2011. The mammalian fauna of Abismo Iguatemi, southeastern Brazil. Journal of Cave and Karst Studies, 73:83-92. doi:10.4311/jcks2010pa0140

Czaplewski, N.J. \& Cartelle, C. 1998. Pleistocene bats from cave deposits in Bahia, Brazil. Journal of Mammalogy, 79:784-803. doi: $10.2307 / 1383089$

Dunn, R.E.; Madden, R.H.; Kohn, M.J.; Schmitz, M.D.; Strömberg, C.A.E.; Carlini, A.A.; Ré, G.H. \& Crowley, J. 2013. A new chronology for middle Eocene-early Miocene South American land mammal ages. GSA Bulletin, 125:539-555. doi:10.1130/ B30660.1

Faure, M.; Guérin, C. \& Parenti, F. 1999. Découverte d'une mégafaune holocène à la Toca do Serrote do Artur (aire archéologique de São Raimundo Nonato, Piauí, Brésil). Comptes Rendu Académie des Sciences, 329:443-448.
Felice, G.D.; Guidon, N. \& Mendes, V.R. 2014. A Evolução da Paisagem no Pleistoceno Superior/Holoceno, na Região do Parque Nacional da Serra da Capivara. In: A. Pessis; G. Martin \& N. Guidon (eds.) Os Biomas e as sociedades humanas na Préhistória da região do Parque Nacional da Serra da Capivara, Brasil, A\&A Comunicação, p. 69-94.

Ferreira, D.; Silva, A.K.B.; Matos, C.H.C.; Hadler, P. \& Hsiou, A.S. 2012. Assembleia holocênica de Vertebrados de pequeno porte do sítio Alcobaça, Estado de Pernambuco, Brasil. Revista Brasileira de Paleontologia, 15:359-370. doi:10.4072/rbp.2012.3.11

Flynn, J.J. \& Wyss, A.R. 2004. A Polydolopine marsupial skull from the Cachapoal Valley, Andean Main Range, Chile. Bulletin of the American Museum of Natural History, 285:80-92. doi:10.1206/0003-0090(2004)285<0080:C>2.0.CO;2

Gardner, A.L. 2008. Mammals of South America, Volume 1 Marsupials, Xenarthrans, Shrews, and Bats. Chicago, Chicago University Press, 690 p.

Goin, F.J. 2001. Marsupiales (Didelphidae: Marmosinae \& Didelphinae). In: D. Mazzanti \& C. Quintana (eds.) Cueva Tixi: Cazadores y recolectores de las Sierras de Tandilia Oriental. 1: Geología, Paleontología y Zooarqueología, Laboratorio de Arqueología, Universidad Nacional de Mar del Plata, p. 75-113.

Goin, F.J.; Pascual, R. \& Tejedor, M.F. 2006. The earliest Tertiary therian mammal from South America. Journal of Vertebrate Paleontology, 26:505-510. doi:10.1671/02724634(2006)26[505:TETTMF]2.0.CO;2

Goin, F.J. \& Rey, P. 1997. Sobre las afinidades de Monodelphis Brunett, 1830 (Mammalia: Marsupialia: Didelphidae: Marmosinae). Neotropica, 43:93-98.

Goin, F.J.; Woodburne, M.O.; Martin, G.M. \& Chornogubsky, L. 2016. A brief history of South American metatherians. Dordrecht, Springer, 237 p. doi:10.1007/978-94-017-7420-8

Gomes, N.F. 1991. Revisão sistemática do gênero Monodelphis (Didelphidae: Marsupialia). Instituto de Biociências, Universidade de São Paulo, Dissertação de Mestrado, 180 p.

Guérin, C. 1991. La Faune de vertébrés du Pléistocène supérieur de l'aire archéologique de São Raimundo Nonato (Piaui, Brésil). Comptes Rendu Académie des Sciences Paris, 312:567-572.

Guérin, C.; Curvelo, M.A.; Faure, M.; Hugueney, M. \& MourerChauviré, C. 1996. The Pleistocene fauna of Piauí (Northeastern Brazil). Palaeoecological and biochronological implications/A fauna pleistoscenica do Piauí (Nordeste do Brasil). Relações paleoecológicas e biocronológicas. Fumdhamentos, 1:55-103.

Guérin, C. \& Faure, M. 2004. Scelidodon piauiense nov. sp., nouveau Mylodontidae Scelidotheriinae (Mammalia, Xenarthra) du Quaternaire de la région du parc national Serra da Capivara (Piauí, Brésil). Comptes Rendus - Palevol, 3:35-42. doi:10.1016/j.crpv.2003.10.007

Guérin, C. \& Faure, M. 2008. La biodiversité mammalienne au Pléistocène supérieur-Holocène ancien dans la Région du Parc National Serra da Capivara (SE du Piauí, Brésil). Fumdhamentos, 7:80-93.

Guérin, C.; Hugueney, M.; Mourer-Chauviré, C. \& Faure, M. 1993. Paléoenvironnement Pléistocène dans L'aire Archéologique de São Raimundo Nonato (Piauí, Brésil): apport des Mammifères et des Oiseaux. Lyon, Faculté des Sciences, p. 187-202 (Documents des laboratoires de géologie 125).

Guidon, N. 1994. O PARNA Serra da Capivara. In: A. Pessis (ed.) Plano de Manejo - Serra da Capivara, Secretaria do Meio Ambiente da Presidência da República, p. 3-15. 
Guidon, N.; Guérin, C.; Faure, M.; Felice, G.D.; Buco, C. \& Ignácio, E. 2009. Toca das Moendas, Piauí-Brasil, primeiros resultados das escavações arqueológicas. Fumdhamentos, 8:70-85.

Guidon, N.; Peyre, E.; Guérin, C. \& Coppens, Y. 2000. Resultados da datação de dentes humanos da Toca do Garrincho, Piauí-Brasil. Clio Série Arqueológica, 14:75-86.

Hadler, P.; Ferigolo, J. \& Goin, F.J. 2009a. Mamíferos de pequeno porte (Didelphimorphia, Chiroptera e Rodentia) do Pleistoceno final/Holoceno do Brasil, com ênfase no Rio Grande do Sul. In: A.M. Ribeiro; S.G. Bauerman \& C.S. Scherer (eds.) Quaternário do Rio Grande do Sul: Integrando Conhecimentos, Porto Alegre, Sociedade Brasileira de Paleontologia, p. 155-170 (Monografias 1).

Hadler, P.; Ferigolo, J. \& Ribeiro, A.M. 2010. Chiroptera (Mammalia) from the Holocene of Rio Grande do Sul state, Brazil. Acta Chiropterologica, 12:19-27. doi:10.3161/150811010X504563

Hadler, P.; Goin, F.J.; Ferigolo, J. \& Ribeiro, A.M. 2009 b. Environmental change and marsupial assemblages in Holocene successions of Southern Brazil. Mammalian Biology, 74:87-99. doi:10.1016/j.mambio.2008.03.003

Hadler, P.; Mayer, E.L.; Motta, F. \& Ribeiro, A.M. 2018. Fossil bats from the Quaternary of Serra da Capivara, northeast Brazil. Quaternary International, 464:411-416. doi:10.1016/j. quaint.2017.11.022

Herrera, L.; D’Andrea, P.S.; Xavier, S.C.C.; Mangia, R.H.; Fernandes, O. \& Jansen, A.M. 2005. Trypanosoma cruzi infection in wild mammals of the National Park 'Serra da Capivara' and its surroundings (Piauí, Brazil), an area endemic for Chagas disease. Transactions of the Royal Society of Tropical Medicine and Hygiene, 99:379-388. doi:10.1016/j.trstmh.2004.07.006

Kerber, L.; Mayer, E.L.; Ribeiro, A.M. \& Vucetich, M.G. 2016. Late Quaternary caviomorph rodents (Rodentia: Hystricognathi) from the Serra da Capivara, northeastern Brazil, with description of a new taxon. Historical Biology, 28:439-458. doi:10.1080/08 912963.2014.967766

Macrini, T.E. 2004. Monodelphis domestica. Mammalian Species, 760:1-8. doi:10.1644/760

Mayer, E.L. 2013. Pequenos mamíferos do Sumidouro do Sansão, Serra da Capivara, Piauí: resultados preliminares. In: CONGRESSO BRASILEIRO DE ESPELEOLOGIA, 32, 2013. Anais, Barreiras, SBE, p. 439-446.

Mendes, V.R. 2016. Registro sedimentar quaternário na Bacia do rio Parnaíba, Piauí: um estudo multi-indicadores voltado à investigação de mudanças climáticas. Universidade de São Paulo, Tese de doutorado, $100 \mathrm{p}$.

Neves, S.B.; Mayer, E.L.; Hadler, P. \& Ribeiro, A.M. 2017. Sigmodontine rodents (Rodentia, Cricetidae) from Quaternary cave deposits of Serra da Capivara, northeastern Brazil, Revista Brasileira de Paleontologia, 20:163-178. doi:10.4072/ rbp.2017.2.02

Novello, V.F.; Cruz, F.W.; Vuille, M.; Strikis, N.M.; Edwards, R.L.; Cheng, H.; Emerick, S.; De Paula, M.S.; Li, X.; Barreto, E.S.; Karmann, I. \& Santos, R.V. 2017. A high-resolution history of the South American Monsoon from Last Glacial Maximum to the Holocene. Scientific Reports, 7:44267. doi:10.1038/srep44267

Oliveira, É.V. 1999. Systematics of Itaboraian (Medial Paleocene) age "opossum like" marsupials from the Itaboraí Basin, Rio de Janeiro, Brazil. Anais da Academia Brasileira de Ciências, 71:811-812.

Oliveira, É.V. \& Goin, F.J. 2011. A reassessment of bunodont metatherians from the Paleogene of Itaboraí (Brazil): Systematics and age of the Itaboraian SALMA. Revista Brasileira de Paleontologia, 14:105-136. doi:10.4072/rbp.2011.2.01

Oliveira, É.V. \& Goin, F.J. 2012. Marsupiais do início do Paleógeno no Brasil: diversidade e afinidades. In: N.C. Cáceres (ed.) Os marsupiais do Brasil: biologia, ecologia e conservação, UFMS, p. 273-305.

Oliveira, É.V.; Villa Nova, P.; Goin, F.J. \& Avilla, L.D.S. 2011a. A new hyladelphine marsupial (Didelphimorphia, Didelphidae) from cave deposits of northern Brazil. Zootaxa, 10:51-62. doi:10.11646/zootaxa.3041.1.3

Oliveira, P.V. 2010. Mamíferos do neopleistoceno: holoceno do Parque Nacional de Ubajara, Ceará. Universidade Federal do Rio Grande do Sul, Programa de Pós-graduação em Geociências, Dissertação de mestrado, 166 p.

Oliveira, P.V.; Lessa, G.; Viana, M.S.S.; Ximenes, C.L.; Ribeiro, A.M.; Oliveira, É.V.; Santos, A.S.T.; Hsiou, A.; Holanda, E.C. \& Kerber, L. 2011b. Gruta do Urso Fóssil (Nordeste Do Brasil) e sua fauna Quaternária: dados preliminares. In: CONGRESSO BRASILEIRO DE PALEONTOLOGIA, 22, 2011. Boletim de Resumos, Natal, SBP, p. 651-653.

Palma, R.E.; Rivera-Milla, E.; Yates, T.L.; Marquet, P. \& Meynard, A.P. 2002. Phylogenetic and biogeographic relationships of the mouse opossum Thylamys (Didelphimorphia, Didelphidae) in southern South America. Molecular Phylogenetics and Evolution, 25:245-253. doi:10.1016/S1055-7903(02)00242-7

Patton, J.; Pardiñas, U.F.J. \& D'Elía, G. 2015. Mammals of South America: Rodents. Chicago, The University of Chicago Press, $1336 \mathrm{p}$.

Paula Couto, C. 1950. Memórias sobre a Paleontologia Brasileira, revistas e comentadas por Carlos de Paula Couto. Rio de Janeiro, Instituto Nacional do Livro, 589 p.

Pavan, S.E. \& Voss, R.S. 2016. A Revised Subgeneric Classification of Short-tailed Opossums (Didelphidae: Monodelphis). American Museum Novitates, 3868:1-44. doi:10.1206/3868.1

Pellerin, J. 2014. Unidades de Relevo e Formações Superficiais na Região do Parque Nacional da Serra da Capivara. In: A.-M. Pessis; G. Martin \& N. Guidon (eds.) Os Biomas e as Sociedades Humanas na Pré-história da Região do Parque Nacional da Serra da Capivara, Brasil: Volume II A., A \& A Comunicação, p. 59-67.

Prado, L.F.; Wainer, I.; Chiessi, C.M.; Ledru, M.P. \& Turcq, B. 2013. A mid-Holocene climate reconstruction for eastern South America. Climate of the Past, 9:2117-2133. doi:10.5194/cp-92117-2013

Ribeiro, A.M.; Mayer, E.L.; Neves, S.B.; Kerber, L.; Motta, F.A.; Ferigolo, J.; Guidon, N. \& Barbosa, M.F.R. 2016. Novas datações holocênicas para pequenos mamíferos da Serra da Capivara, Piauí, Brasil. In: SIMPÓSIO BRASILEIRO DE PALEONTOLOGIA DE VERTEBRADOS, 10, 2016. Anais, Rio de Janeiro, SBP, p. 192.

Rodet, J. 1997. As zonas cársticas de São Raimundo Nonato (Piauí, Brasil). O Carste, 9:2-7.

Rossi, R.V.; Brandão, M.V.; Carmignotto, A.P.; Miranda, C.L. \& Cherem, J.J. 2012. Diversidade morfológica e taxônomica de marsupiais didelfídeos, com ênfase nas espécies brasileiras. In: N.C. Cáceres (ed.) Os marsupiais do Brasil: biologia, ecologia e conservação, UFMS, Campo Grande, p. 23-72.

Rowe, T. 1988. Definition, diagnosis and origin of Mammalia. Journal of Vertebrate Paleontology, 8:241-264

Salles, L.O.; Cartelle, C.; Guedes, P.G.; Boggiani, P.C.; Janoo, A. \& Russo, C.A.M. 2006. Quaternary Mammals from Serra da 
Bodoquena, Mato Grosso do Sul, Brazil. Boletim do Museu Nacional, Nova Série Zoologia, 521:1-12.

Salles, L.O.; Carvalho, G.S.; Weksler, M.; Sikuro, F.L.; Abreu, F.; Camardella, A.R.; Guedes, P.G.; Avilla, L.S.; Abrantes, E.A.P.; Sahate, V. \& Costa, I.S.A. 1999. Fauna de mamíferos do Quaternário de Serra da Mesa (Goiás, Brasil). Publicações Avulsas do Museu Nacional, 78:1-15.

Santos, M.E. \& Carvalho, M.S.S. 2009. Paleontologia das bacias do Parnaíba, Grajaú e São Luís. Rio de Janeiro, Serviço Geológico do Brasil - DGM/DIPALE, 215 p.

Sedor, F.A.; Oliveira, É.V.; Silva, D.D.; Fernandes, L.A.; Cunha, R.F.; Ribeiro, A.M. \& Dias, E.V. 2017. A New South American Paleogene Land Mammal fauna, Guabirotuba Formation (Southern Brazil). Journal of Mammalian Evolution, 24:39-55. doi:10.1007/s10914-016-9364-7

Silva, L.G.L.; Lopes, F.E.S; Paz, R.L.; Alves, M.H. \& Lima, R.N. 2011. Riqueza de mamíferos terrestres não voadores na região centro-oeste e sul do Piauí. In: CONNEPI, 6, 2011. Anais, Natal, IFRN.

Villa Nova, P.; Avilla, L.S. \& Oliveira, E.V. 2015. Didelphidae marsupials (Mammalia, Didelphimorphia) from the Late Pleistocene deposit of the Gruta dos Moura Cave, northern Brazil. Anais da Academia Brasileira de Ciências, 87:193-208. doi:10.1590/0001-3765201520140229

Voss, R.S.; Gutiérrez, E.E.; Solari, S.; Rossi, R.V. \& Jansa, S.A. 2014. Phylogenetic relationships of mouse opossums (Didelphidae, Marmosa) with a revised subgeneric classification and notes on sympatric diversity. American Museum Novitates, 3817:1-27. doi:10.1206/3817.1
Voss, R.S. \& Jansa, S.A. 2009. Phylogenetic relationships and classification of didelphid marsupials, an extant radiation of New World metatherian mammals. Bulletin of the American Museum of Natural History, 322:1-177.

Voss, R.S.; Lunde, D.P. \& Jansa, S.A. 2005. On the contents of Gracilinanus Gardner and Creighton, 1989, with the description of a previously unrecognized clade of small didelphid marsupials. American Museum Novitates, 3482:1-36.

Voss, R.S.; Lunde, D.P. \& Simmons, N.B. 2001. The mammals of Paracou, French Guiana: a Neotropical lowland rainforest fauna Part 2. Nonvolant species. Bulletin of the American Museum of Natural History, 263:3-236.

Waldherr, F.R.; Araújo-Júnior, H.I. \& Rodrigues, S.W.O. 2017. Origem e morfologia dos tanques naturais do Nordeste do Brasil. Pesquisas em Geociências, 44:467-488. doi:10.22456/18079806.83270

Winge, H. 1893. Jordefundne og nulevende Pugdyr (Marsupialia) fra Lagoa Santa, Minas Geraes, Brasilien. E. Museo Lundii, 2:1-149.

Woodburne, M.O.; Goin, F.J.; Raigemborn, M.S.; Heizler, M.; Gelfo, J.N. \& Oliveira, E.V. 2014. Revised timing of the South American early Paleogene land mammal ages. Journal of South American Earth Sciences, 54:109-119. doi:10.1016/j. jsames.2014.05.003

Received in 01 March, 2019; accepted in 10 September, 2019. 
Appendix 1. List of the studied fossils. Abbreviations: ID, rD, left and right dentary, respectively; IMx, rMx, left and right maxillary, respectively; C, c, upper and lower canines, respectively; P1,P2, P3, p1, p2, p3, upper and lower first, second and third pre-molars, respectively; M1, M2, M3, M4, m1, m2, m3, m4, upper and lower first, second, third and fourth molars, respectively; edent, toothless.

Toca do Serrote das Moendas: Didelphis albiventris FUMDHAM 113-145978 - rD m1-m3; Monodelphis domestica FUMDHAM 113-121608-2 - rD. p3-m3; FUMDHAM 113-122546-2 - rD. p2-m4; FUMDHAM 113-123453-2 - 1D. m1-m2; FUMDHAM 113-138001 - rD. m1-m4; FUMDHAM 113143298-3 - 1D. m1-m4; FUMDHAM 113-144938 - rD. p2-m4; FUMDHAM 113-144977 - 1D. m4; FUMDHAM 113-145505-2 - rD. m3-m4; FUMDHAM 113-145752-2 - 1D. p3-m3 + m4 loose; Cryptonanus agricolai FUMDHAM 113-137841-2 -rD. m2-m4; FUMDHAM 113-137852-3 A - 1D. m4; FUMDHAM 113-137857-3 - rD. p2-m4; rD. p3-m3 + m4 loose; Gracilinanus agilis FUMDHAM 113-144366-2 - 1D. p2-m4; Didelphinae indet. FUMDHAM 113144366-2 - 1D. p2-m4.

Toca do Gordo do Garrincho: Monodelphis domestica FUMDHAM 200-22304-7 B - 1D. edent; FUMDHAM 200-60900-3 A - rD. p3-m4; rD. edent.; FUMDHAM 200-63207-2 - 1Mx. P2-M4; Gracilinanus agilis FUMDHAM 200-22304-7 A - 1D. m3-m4; Didelphinae indet. FUMDHAM 200-60900-3 $\mathrm{B}-\mathrm{rD}$. edent.

Toca do Serrote do Artur: Didelphis albiventris FUMDHAM 227-47942-3 B - 2 D. edent., FUMDHAM 227-48439-4 C-rD. m4; FUMDHAM 227-49012-2 B - isolated m2; Monodelphis domestica FUMDHAM 227-45004-4 B - rD. m1-m3; FUMDHAM 227-45016-4 - rD. c-p1, m1-m3; ID. edent.; FUMDHAM 227-45868-3 - 1D. p3-m2; FUMDHAM 227-47437-5 - 1Mx. P2-M4; 1Mx. M2-M3 + M4 loose; 1D. m1-m4; 4 1D. edent.; 4 rD. edent.; FUMDHAM 22747440-3 - 1Mx. P2-M4; 1D. edent; FUMDHAM 227-47445-2 - 1D. m1-m4; rD. m3-m4; FUMDHAM 227-47446-1 C - rD. m3-m4; rD. m1; 3 1D. edent.; 4 rD. edent.; rMx. P3-M4; 1Mx. M4; 1Mx. P2-P3; FUMDHAM 227-47487-4 A -1D. m1; rD. edent.; FUMDHAM 227-47606-3 - rD. edent.; FUMDHAM 227-47620-5 C - 1D. p3-m1; rMx. P3, M2-M3; FUMDHAM 227-47626-3 - 2 1D. edent.; FUMDHAM 227-47630-4 A - 1D. m1; rD. edent; FUMDHAM 227-47639-2 - rD. edent.; FUMDHAM 227-47646-3 C-1D. edent; FUMDHAM 227-47654-3 A-rD. c, p2; rD. p3-m4; 1D. p2-m4; 1D. p2-m1; FUMDHAM 227-47664-3 - rMx. P3-M4; FUMDHAM 227-47926-1 -rD. edent; FUMDHAM 227-47936-4 B - rD. m3-m4; FUMDHAM 227-47942-3 A - rD. m4; 2 1D. p3-m2; FUMDHAM 227-47943-2 - 1Mx. M2-M3; 2 1D. edent.; rD. edent.; FUMDHAM 227-47945-3 A-1D. m4; 2 rD. edent.; 3 1D. edent.; FUMDHAM 227 47950-4 A - rD. m2; 1D. edent.; rD. m1; rD. m1-m3; rD. p2-m1; 1Mx. P3-M4; FUMDHAM 227-47952-4 - 1D. edent.; rD. p3-m4; FUMDHAM 227-47952-5 A - rD. p3-m1; FUMDHAM 227-47985-4 - 1D. edent.; FUMDHAM 227-47986-3 - 1D. p2-m3; rD. m2-m4; FUMDHAM 227-48405-4 C - rD. m3; rD. p2-m1; 1D. m2; 1D. m2-m4; 1D. p2, m1-m2; rD. edent.; FUMDHAM 227-48439-4 B - rD. c, p2-m2; FUMDHAM 227-48444-6 - 1D. m2-m3; FUMDHAM 227-48455-2 B - rD. edent; FUMDHAM 227-48497-3 - 1D. p3-m1; FUMDHAM 227-49008-3 A - rD. edent.; 2 1D. edent.; FUMDHAM 227-49056-3 - rD. p3-m1; FUMDHAM 227-49064-3 -1D. p2-m1; 1D. m3-m4; rD. p2; FUMDHAM 227-49065-1 -rD. p2; rD. m1-m4; FUMDHAM 227-49072-3 C-1D. edent + loose premolar; Monodelphis americana FUMDHAM 227-47646-3 A-rD. m1,m2-m4; Cryptonanus agricolai FUMDHAM 227-47620-5 B - 1D. m3-m4; FUMDHAM 227-47654-3 C - 1D. p2-m2; FUMDHAM 227-47936-4 A-rD. m4, rD. p2-m3; FUMDHAM 227-48405-4 B - 1D. m1-m4; FUMDHAM 22748455-2 A - 1D. p3-m4; FUMDHAM 227-49012-2 A - 1D. m3; Gracilinanus agilis FUMDHAM 227-47446-1 A - rD. m2; FUMDHAM 227-47467-3 - rD. m3-m4; FUMDHAM 227-47620-5 A - rD. m4; FUMDHAM 22747630-4 B - 1D. m4; FUMDHAM 227-48405-4 A - 1D. m1-m4; FUMDHAM 227-48439-4 A - 1D. m3-m4; FUMDHAM 227-49072-3 A - 1D. c, p2-m3; Thylamys karimii FUMDHAM 227-45004-4 A - 1D. i5-m4; FUMDHAM 227-47654-3 B - rD. c-m4; FUMDHAM 227-47664-2 - rMx. C-M4; FUMDHAM 227-49072-3 B - 1D. p3-m1, m4; rD. p3-m2; Didelphinae indet. FUMDHAM 227-47446-1 B - 3 1D. edent; 2 rD. edent.; FUMDHAM 227-47487-4 B - 1D. edent.; FUMDHAM 227-47620-5 D - 1D. edent.; FUMDHAM 227-47630-4 C - 2 rD. edent; 1D. edent.; FUMDHAM 227-47646-3 B - rD. edent.; FUMDHAM 227-47654-3 D - rD. edent.; FUMDHAM 227-4785-4 B - 2 rD. edent; FUMDHAM 227-47945-3 B - rD. edent.; FUMDHAM 227-47950-4 B - rD. edent.; FUMDHAM 227-48405-4 D - rD. edent.; FUMDHAM 227-49008-3 B - rD. edent. Toca do Barrigudo: Didelphis albiventris FUMDHAM 444-77765 - rD. m4; FUMDHAM 444-77783 - 1D. p3, m2-m3; FUMDHAM 444-78424-6 E - D. edent.; FUMDHAM 444-78429-7 D - 1D. edent.; FUMDHAM 444-78903-4 C - rD. edent.; FUMDHAM 444-79156-5 E - 2 D. edent.; Monodelphis domestica FUMDHAM 444-76164-2 - 1D. m3; FUMDHAM 444-76185-2 B-rD. m1-m4; rD. m3-m4; 2 rD. edent.; FUMDHAM 444-77715-4 C- 1D. m3-m4; 2 rD. edent.; 2 1D. edent.; FUMDHAM 444-78424-6 D - 1Mx. M1-M4; rMx. M1-M2; rMx. M1-M4; rD. m3; rD. m4; 1D. m1-m3; 9 rD. edent.; 5 1D. edent.; 1Mx. edent.; FUMDHAM 444-78429-7 C - rMx. M1-M3; 1Mx. M2-M3; 1Mx. M1-M2; 1Mx. P3-M3; 1Mx. M3-M4; 1Mx. edent.; 1D. m3-m4; 1D. m4; 1D. m1-m2; 1D. p3-m3; 1D. p3-m4; rD. p3-m4; rD. m4; rD. p3; rD. m3; 12 rD. edent.; 10 1D. edent. + loose teeth; FUMDHAM 444-78438-4 - 1Mx. M1-M3; 1D. m4; 3 1D. edent.; FUMDHAM 444-78660-4 B - 1D. m2; rD. m1 + molar; rD. edent.; 1D. edent.; FUMDHAM 444-78903-4 A - 2 1D. m1-m4; 1D. m4; 1D. m1; 1D. edent.; FUMDHAM 444-78911-3 A - 1Mx. P3-M4; 1D. edent.; FUMDHAM 444-78913 - rD. p3-m4; rD. edent.; FUMDHAM 444-78983-3 - rD. m1-m2; FUMDHAM 444-79089-2 A - 1D. m1; rD. m3-m4; rMx. M2; FUMDHAM 444-79156-3 B - rD. m1-m2; rD. p3-m2 + loose tooth; 1D. edent.; FUMDHAM 444-79156-5 D - 1Mx. M3; rMx. M1-M4; rMx. M2-M3; rMx. P2-M4; 3 rD. m4; rD. m3-m4; rD. p3-m4; rD. m2-m4; rD. p3-m3; rD. edent.; rD. m1-m4; 3 1D. m4; 1D. p3-m1; 1D. p3-m3; 1D. p2-m3; 1D. p2-m1; 1D. m1-m4; 1D. m2-m3; 1D. p2; 1D. m1; 1D. p2-p3, m4; rD. p2-m4; 18 1D. edent.; 16 rD. edent.; FUMDHAM 444-79315-2 - 1D. m1-m2; Cryptonanus agricolai FUMDHAM 444-76185-2 A - rD. m2-m4; Gracilinanus agilis FUMDHAM 444-77715-4 B - 1D. p1-p2, m4; FUMDHAM 444-78424-6 A - 1D. m2-m4; FUMDHAM 444-78429-7 A - rD. m1-m3; rD. m2-m4; rD. m1-m4; rD. p3-m4; 1D. p2-m4; 1D. p3-m4; 1D. m1-m4; 1D. p2,m4; FUMDHAM 444-78660-4 A-rD. m1-m3 + loose tooth; FUMDHAM 444-78903-4 B -rD. p3 + loose tooth; FUMDHAM 444-79156-3 A - 1D. m1-m2; 1D. m2-m3; FUMDHAM 444-79156-5 A - rD. p3-m4; rD. m3-m4; 1D. p3-m3; 1D. m3-m4; ID. p2-p3; 1D. edent.; loose teeth; Thylamys karimii FUMDHAM 444-77715-4 A - 1D. p3-m3; FUMDHAM 444-78424-6 B - 1Mx. P2-M4; FUMDHAM 444-78429-7 E - rD. m4; 1D. c, p2-m1 (1 and 2); FUMDHAM 444-79009-3 - 1D. p2-m2, m4; FUMDHAM 444-79156-5 C - rD. m4 + loose teeth; Didelphinae indet. FUMDHAM 444-78424-6 C - 2 rD. edent.; 1D. edent.; FUMDHAM 444-78429-7 B - 8 rD. edent.; 7 1D. edent.; FUMDHAM 444-78660-4 C - 2 rD. edent.; 1D. edent.; FUMDHAM 444-78903-4 D - rD. edent.; 1D. edent.; FUMDHAM 444-79089-2 B-rD. edent.; FUMDHAM 444-79156-3 C-rD. edent.; FUMDHAM 44479156-5 B- 5 rD. edent.; 8 1D. edent. 
Appendix 2. List of recent specimens used for comparison.

Cryptonanus sp., UFPE 1174, UFPE 1862, UFPE 2998, UFPE 3014;

Cryptonanus guahybae, UFSC 5203, UFSC 5234, UFSC 5434;

Gracilinanus sp., UFPE 1842, UFPE 2981, UFPE 2982, UFSC 2585, UFSC 2586, UFSC 2587;

Gracilinanus agilis, UFSC 2819, UFSC 5217, UFSC 5218, UFSC 5219, UFSC 5220, UFSC 5221, UFSC 5707;

Gracilinanus microtarsus, UFSC 2428, UFSC 2429, UFSC 2430, UFSC 2431, UFSC 3851, UFSC 5893;

Marmosa sp., UFPE 2915, UFPE 2918, UFPE 2925, UFPE 2926, UFPE 2927, UFPE 2931, UFPE 2933, UFPE 3011;

Marmosa (Micoureus) demerarae, UFSC 4772, UFSC 4773;

Marmosa (Micoureus) paraguayanus, UFSC 2426, UFSC 2427, UFSC 4851, UFSC 5065;

Marmosa murina, UFSC 4726, UFSC 4727;

Marmosops sp., UFSC 2432, UFSC 2433, UFSC 2436, UFSC 2447, UFSC 2452;

Monodelphis americana, UFSC 2584;

Monodelphis domestica UFSC 2818, UFSC 4775, UFSC 4776, UFSC 4782;

Monodelphis glirina, UFSC 5209. 